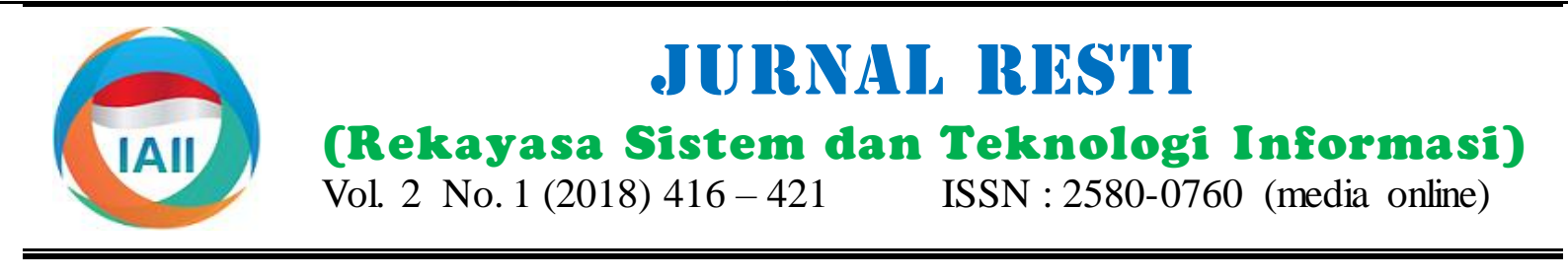

\title{
Implementasi Sistem Informasi Penggajian Untuk Membantu Manajemen Keuangan Dalam Pengolahan Usaha
}

\author{
Mira Susantia ${ }^{a}$ Rasman Hidayatullah ${ }^{b}$ \\ ${ }^{a}$ Manajemen Informatika, Amik Bukittinggi, mira_0310021@yahoo.com \\ ${ }^{\mathrm{b}}$ Manajemen Informatika, Amik Bukittinggi, rasman_ibnuauf@yahoo.co.id
}

\begin{abstract}
The era of globalization also affects the business environment in data processing in the form of transactions such as payroll. If the process of payroll calculation is slow and prone to error can lead to discontinuity between employees and management and the use of conventional systems also lead to data security is not guaranteed then the required system that supports management needs in the form of payroll information system to minimize errors that can be used in decision making and influence to smooth business. The method used is the System Development Life Cycle (SDLC) which is a guide in designing and developing information systems. Implemented payroll information systems are able to generate accurate payroll reports in the form of loan evidence, employee salary recaps making it easier to control profits-related businesses to create sound financial management.
\end{abstract}

Keywords: Payroll, Information Systems, Financial Management

\begin{abstract}
Abstrak
Era globalisasi juga berpengaruh pada lingkungan bisnis dalam pengolahan data berupa transaksi seperti penggaiian. Jika proses perhitungan penggajian lambat dan rentan terhadap kesalahan dapat menimbulkan ketidakpuasan antara karyawan dengan manaiemen serta penggunaan sistem vang masih konvensional iuga menvebabkan keamanan data tidak teriamin maka diperlukan sistem y ang mendukung kebutuhan manaiemen berupa sistem informasi penggaiian untuk meminimalkan kesalahan y ang dapat digunakan dalam pengambilan keputusan dan berpengaruh terhadap kelancaran usaha. Metode yang digunakan adalah System Development Life Cycle (SDLC) yang menjadi pedoman dalam merancang dan mengembangkan sistem informasi. Sistem informasi penggajian y ang sudah diimplementasikan mampu menghasilkan laporan penggajian yang akurat berupa bukti pinjaman, rekap gaji karyawan sehingga memudahkan dalam mengontrol usaha yang berkaitan dengan keuntungan untuk menciptakan manajemen keuangan yang bagus.
\end{abstract}

Kata kunci: Penggajian, Sistem Informasi, Manajemen Keuangan

(C) 2018 Jurnal RESTI

\section{Pendahuluan}

Dengan melihat perkembangan teknologi bukanlah suatu hal yang berlebihan jika komputer dikatakan sebagai alat sosial karena pada kenyataanya teknologi ini dipergunakan secara intensif pada berbagai komunitas masyarakat seperti institusi, organisasi, dunia usaha. Pemanfaatan teknologi komputer[1] dapat berpengaruh terhadap pola kehidupan masyarakat yang memakainya. Saat ini masih ada perusahaan dalam mengolah data-data penting masih menggunakan konsep manual terlebih lagi data tersebut sangat berpengaruh sekali terhadap pengambilan keputusan contohnya pada us aha konveksi Nofi gorden sampai saat ini masih belum mengoptimalkan komputer dalam pengolahan data-data Sebagaimana diketahui sistem yang penerapannya penting seperti pengolahan data barang yang akan belum mengoptimalkan komputerisasi atau sistem dijahit, menghitung total pinjaman karyawan dan menghitung total barang yang sudah dijahit dimana hasilnya nanti akan menentukan berapa gaji karyawan hal ini memiliki kelemahan dalam memproses data baik mencatatnya maupun dalam proses menghitung[2] sehingga membutuhkan waktu yang lebih lama. Masalah lain yang sering terjadi adalah tidak akurat upah dan gaji yang diterima karyawan karena kesalahan pencatatan dan tidak adanya bukti slip penerimaan gaji. Manajemen keuangan yang dterapkan dalam suatu usaha juga bisa memberikan gambaran pemasukan dan pengeluaran untuk keperluan usaha untuk itu sistem informasi juga menggambarkan profit dari suatu usaha. 
informasi memberikan efek kurang teliti dan cermat dalam mengolah dan memproses data, tentu hal inidapat menyebabkan terjadinya kesalahan saat mencatatnya (input) dan laporan-laporan (output)[3] yang dihasilkan dari proses tersebut tentu kurang informatif dengan demikian kinerja usaha rumahan akan kurang maksimal dan kurang efektif dalam pengambilan keputusannya terlebih lagi ketika proses penghitungan total jahitan, pinjaman karyawan dan penghitungan gaji karyawan dengan anggota karyawan jahit yang banyak tentu membutuhkan waktu untuk menghitungnya sehingga gaji karyawan pun tidak akan keluar pada saat dibutuhkan.

Adapun tujuan penelitian sebagai berikut :

1. Membangun sistem informasiyang diharapkan dapat memudahkan pemilik usaha konveksi Nofi gorden dalam pengolahan data jahitan, proses pengolahan data jahit pesanan dan proses pengolahan data pinjaman karyawan, data penggajian karyawan.

2. Menghasilkan informasi terstruktur dan sistematis dalam menentukan upah jahit dan penggajian karyawan usaha konveksi Nofi gorden.

3. Mempercepat dan mempermudah pemilik Usaha konveksi Nofi gorden dalam proses pengambilan suatu keputusan berdasarkan laporan yang diterima

\section{Tinjauan Pustaka}

\subsection{Perancangan Sistem}

Pentingnya informasi digunakan dalam manajemen sebagai alat dalam pengambilan keputusan dan bisa digunakan untuk mengetahui perkembangan organis asi dan lingkungan serta untuk perencanaan strategis untuk masa yang akan datang. Proses perancangan sistem juga menentukan hasil rancangan sistem yang tepat dan sistem lebih stabil serta memudahkan untuk dikembangkan dimasa mendatang[4]. Perancangan sistem memiliki tujuan untuk memenuhi kebutuhan pengguna sistem dan memberikan gambaran yang jelas dan rancang bangun yang lengkap pada pemrograman komputer dan melibatkan ahli-ahli tekniknya. Sebuah sistem dapat saja berbentuk abstrak maupun fisik. Sistem abstrak adalah suatu susunan teratur, gagasan atau konsep yang saling ketergantungan. Sistem fisik adalah sebuah sistem terdiri dari bagian-bagian yang saling berkaitan dan berarti, dan terd iri dariunsur-unsur yang dapat dikenal sebagai saling melengkapi karena satunya maksud dan tujuan. Jadi, sebuah sistem informasi merupakan hal yang sangat penting bagi manajemen didalam pengambilan keputusan.

Dengan memahami sistem sebelumnya dan kriteriakriteria sistem yang dibangun maka peneliti dapat membuat rancangan sistem seperti yang diinginkan.

Dengan memperhatikan studi kelayakan terhadap sistem yang dirancang maka harus menganalisis beberapa hal yaitu : a. Kebutuhan perusahaan, yaitu dengan memahami bidang bisnis yang dikembangkan, sasaran yang akan dijadikan pangsa pasar yang dibidik serta media yang digunakan.Kebutuhan operator yaitu kemudahan dalam penggunaan sistem, dioperasikan dan interface yang interaktif.

b. Kebutuhan pemakai yaitu kebutuhan konsumen terhadap sistem Informasi, dalam hal ini konsumen yang melakukan transaksi

\subsection{Penggajian}

Gaji yang diterima karyawan merupakan bentuk penghargaan atas pekerjaan[5] dan prestasi yang telah dilakukan berdasarkan jenjang jabatan seperti manajer, pegawai administrasi, supervis or dan lain-lain yang pada umumnya gaji dibayarkan tetap tiap bulan.. Namun gaji dan upah[6] mempunyai perbedaan yang terletak pada kekuatan kontrak kerja dan jangka waktu penerimaan. Berdasarkan jangka waktu penerimaan, seseorang yang menerima gaji akan diberikan setiap akhir bulan sedangkan seseorang yang menerima upah akan diberikan setiap hari atau minggu.

Fungsi yang berkaitan dengan sistem penggajian

1. Fungsi Kepegawaian

Bertanggung jawab merekrut karyawan baru, menentukan penempatan kerja karyawan

2. Fungsi pencatat waktu Menyelenggarakan catatan waktu hadir bagi semua karyawan perusahaan.

3. Fungsi pembuat daftar gaji Membuat daftar gaji yang berisi penghasilan yang dikurangi dengan berbagai potongan yang menjadi beban setiap karyawan selama jangka waktu pembayaran gaji.

4. Fungsi akuntansi

Mencatat kewajiban yang timbul dalam hubungannya dengan pembayaran gaji karyawan misalnya utang gaji, utang pajak, utang dana pensiun.

5. Fungsi keuangan

Bertugas melakukan pembayaran gaji kepada karyawan baik secara tunai maupun non tunai.

\subsection{Crystal Report}

Dalam merancang sistem diperlukan program khusus yang digunakan untuk membuat laporan dan memudahkan program aplikasi yang digunakan. Crystal report [7]merupakan software output yang dibutuhkan untuk merancang sistem agar dapat digunakan oleh user, crystal report juga dapat mendesain laporan yang dihasilkan menjadi lebih menarik sesuai keinginan, dan laporan-laporan penting yang dihasilkan. Crystal report dalam merancang sistem informasi membutuhkan sebuah software seperti Borland Delphi 7.0 [8] sebagai interface tetapi keduanya dapat dihubungkan. 
Kemudahan penggunaan crystal report seperti:

a. Membuat laporan tanpa melibatkan kode pemrograman yang terlalu rumit

b. Bis a mengekspor laporan untuk dijadikan format umum seperti pdf, doc.

c. Rancangan laporan bisa dengan menambahkan grafik, penggunaan model bisnis dan bisa berinteraksi pemrograman berorientasi objek.

\section{Metodologi Penelitian}

Metodologi yang umum dibidang komputer yaitu Sistem Development Life Cycle (SDLC). Langkah-langkah atau pedoman pada SDLC [9] seperti pada Gambar 1 tentang siklus pengembangan sistem informasi dimulai dari perencanaan berupa survei dan analisis untuk memudahkan dalam desain, coding, implementasi dan pemeliharaan.

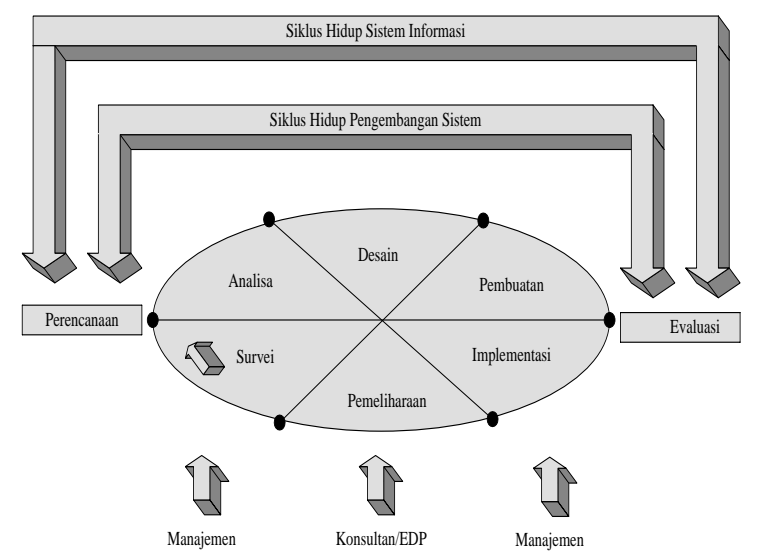

Gambar 1. Siklus Pengembangan Sistem

Langkah pengembangan sistem informasi antara lain:

1. Analisis, bertujuan untuk memahami sistem yang ada, mengidentifikasi masalah dan mencari solusinya.

2. Desain, bertujuan untuk mendesain sistem baru yang dapat menyelesaikan masalah-masalah yang dihadapi.

3. Pembuatan, membuat sistem baru (hardware, software).

4. Implementasi, bertujuan mengimplementasikan sistem yang baru.

Secara konseptual siklus pengembangan sebuah sistem informasi adalah sebagai berikut[10] :

a. Analisis Sistem

Menganalisis dan mendefinisikan masalah dan kemungkinan solusinya untuk sistem informasi dan proses organisasi.

b. Perancangan Sistem

Merancang output, input, struktur file, program, prosedur,perangkat keras dan perangkat lunak yang diperlukan untuk mendukung sistem informasi. pada Gambar 2 tentang aliran sistem informasi penggajian untuk menentukan alur sistem agar menghasilkan sistem yang tepat c. Pembangunan dan Testing Sistem

membangun perangkat lunak yang diperlukan untuk mendukung sistem dan melakukan testing secara akurat. Melakukan instalasi dan testing terhadap perangkat keras dan mengoperasikan perangkat lunak.

d. Implementasi Sistem

beralih dari sistem lama ke sistem baru, melakukan pelatihan dan panduan seperlunya.

e. Operasi dan Perawatan mendukung operasi sistem informasi dan melakukan perubahan atau tambahan fasilitas.

f. Evaluasi Sistem

mengevaluasi sejauh mana sistem telah dibangun dan seberapa bagus sistem telah dioperasikan.

\section{Pembahasan dan Hasil}

Ada beberapa skenario yang diterapkan pada sistem yang sedang berjalan seperti bahan gorden yang sudah dijahit kemudian dicatat kedalam buku catatan jahitan harian oleh karyawan sebagai bukti dari hasil jahitan setiap harinya kemudian pengelola usaha menghitung total bahan yang dijahit dimana proses penghitungan total bahan yang dijahit berdasarkan jenis bahan dan keterangan jahitan selanjutnya disalin kedalam buku besar untuk diberikan kepada pimpinan. Bagi karyawan melakukan peminjaman keuangan untuk keperluan sehari-hari sebelum gaji dikeluarkan oleh pengelola usaha maka akan dicatat oleh pengelola usaha kedalam buku pinjaman karyawan dan diberikan kepada pimpinan sehingga setiap bulan akan terjadi pemotongan gaji berdasarkan jumlah pinjaman karyawan setelah dievaluasi oleh pengelola usaha dan pimpinan sehingga menimbulkan kelemahan diantaranya update pengolahan data berupa informasi jahitan tidak maksimal, tidak akurat penghitungan total jahitan, total upah jahit, total pinjaman serta pemberian gaji tidak tepat waktu. Penggunaan sistem informasibisa pengolahan data, pemprosesan dan laporan yang dihasilkan bisa sesuai dengan kebutuhan. Penggunaan sistem informasi penggajian berkaitan erat dengan manajemen keuangan karena menentukan keberlangsungan suatu usaha dimasa yang akan datang, jika manajemen keuangan bagus dan penyususanannya juga terstruktur maka jumlah pemasukan dan pengeluaran juga lebih jelas. Untuk mengatasi permasalahan tersebut sehingga dirancang sistem informasi secara berupa :

a. Pengolahan data jahitan dilakukan dengan menggunakan sistem informasi yang terdiri dari proses entry data dan manipulasi data serta pengaturan tentang data-data yang berhubungan dengan proses pengolahan data upah jahit dan penggajian karyawan. 
b. Data disimpan kedalam database kemudian data Database yang dirancang terdiri dari tabel karyawan, dalam database tersebut diolah sehingga dapat barang, tarif, jahitan, jahit pesanan, pinjaman, upah jahit, menghasilkan informasi yang lebih cepat dan akurat. gaji karyawan dan pengelola, salah satu tabel yang

c. Proses penghitungan dilakukan sepenuhnya secara digunakan dalam database adalah tabel data jahit terkomputerisasi sehingga proses penghitungan tidak pesanan yang ada pada Tabel 1. Setiap tabel mempunyai menghabiskan waktu yang begitu lama dan field masing-masing salah satunya berfungsi sebagai informasi yang dihasilkan pun lebih cepat diperoleh primary key atau sebagai foreign key dan tabel tersebut serta kerahasiaan data pun akan lebih terjamin. akan digunakan sebagai pemprosesan data masukan dimana data yang akan diproses harus dimasukkan

Pada aliran sistem informasi penggajian memiliki tiga terlebih dahulu tentunya melalui interface (perangkat entity diantaranya karyawan, pengelola usaha konveksi penghubung) antara pengguna dengan hardware dan dan pimpinan yang terdapat pada gambar 2 untuk software. Adanya field pada setiap tabel memudahkan menentukan alur sistem agar menghasilkan sistem untuk merelasikan dengan tabel yang lainnya sehingga informasi yang tepat dimana bukti catatan jahitan yang terbentuk database yang membantu untuk menyimpan

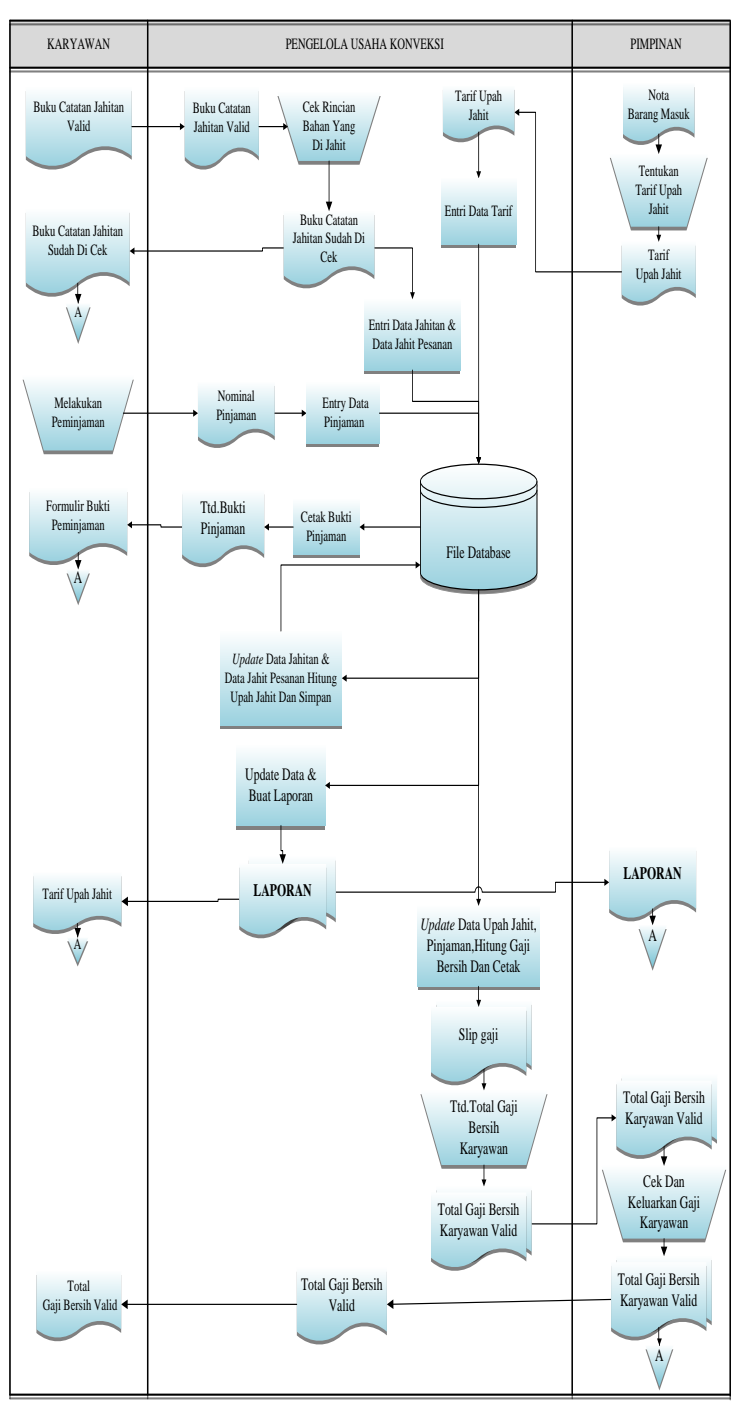

Gambar 2. Aliran Sistem Informasi data yang di entrykan dengan perantara interface program upah jahit dan penggajian.

Tabel 1.Desain file tabel data jahit pesanan

\begin{tabular}{|c|c|c|}
\hline Nama Field & $\begin{array}{l}\text { Type } \\
\text { (Width) }\end{array}$ & Description \\
\hline NoEntrian & $\begin{array}{l}\text { Varchar } \\
(25)\end{array}$ & No entrian data \\
\hline Tanggal & Date & $\begin{array}{l}\text { Tanggal entrian } \\
\text { data }\end{array}$ \\
\hline Bulan & varchar(19) & Bulan \\
\hline IDKaryawan & $\operatorname{varchar}(20)$ & ID karyawan \\
\hline NmBarang & $\operatorname{varchar}(35)$ & Nama barang \\
\hline Warna & $\operatorname{varchar}(20)$ & Warna barang \\
\hline $\begin{array}{l}\text { KeteranganHit } \\
\text { ungan }\end{array}$ & varchar(16) & $\begin{array}{l}\text { Keterangan } \\
\text { hitungan jahitan }\end{array}$ \\
\hline Ukuran & $\operatorname{varchar}(5)$ & Ukuran pesanan \\
\hline Banyak & $\operatorname{int}(20)$ & Banyak jahitan \\
\hline Ket_jahitan & varchar(20) & $\begin{array}{l}\text { Keterangan } \\
\text { jahitan }\end{array}$ \\
\hline
\end{tabular}

Penggunaan flowchart membantu untuk merepresentasikan aktivitas tertentu pada perancangan system informasi seperti pada Gambar 3 merupakan flowchart yang diterapkan pada proses penghitungan upah jahit pesanan memberikan gambaran tentang logika penghitungan upah jahit yang dihubungan denga data pesanan, data karyawan, data tarif, data keterangan jahitan. Jika akan menginput data yang baru akan dimulai dengan input data id karyawan disini diterapkan proses penghitungan yang lebih cepat dari manual karena bisa menghitung upah jahit pesanan dan gaji bersih secara otomatis sehingga informasi yang diterima oleh pimpinan dan karyawan lebih valid kecuali kesalahan human error.

Dalam setiap pemprosesan perlu ada data masukan, dimana data yang akan diproses harus dimasukkan terlebih dahulu, tentunya melalui interface (perangkat penghubung) antara user dengan sistem informasiyang dirancang. Untuk itu agar memudahkan dan meminimalkan kesalahan dan memudahkan entry data maka dirancang bentuk menu tampilan yang mudah digunakan untuk memasukkan data seperti form login yang berfungsi untuk menentukan hak akses dari user yang telah ditentukan, form utama menggambarkan

valid diberikan oleh karyawan kepada pengelola usaha konveksi untuk di cek dan dientrykan datanya kedalam aplikasi penggajian. Karyawan juga diizinkan untuk mengajukan pinjaman yang kemudian diproses oleh sistem untuk mencetak bukti pinjaman, pengelola konveksi bertugas membuat laporan yang akan dis erahkan kepada pimpinan. 
logika dan urutan dari penggunaan sistem informasi mulai dari entry data sampai cetak laporan. Pada menu utama terdiri dari desain input yang berfungsi input data, desain proses dirancang untuk memudahkan mengupdate dan menghitung data dan desain output berupa laporan yang ditampilkan sesuai dengan kebutuhan user maka dirancang bentuk menu tampilan yang mudah digunakan untuk memasukkan data.

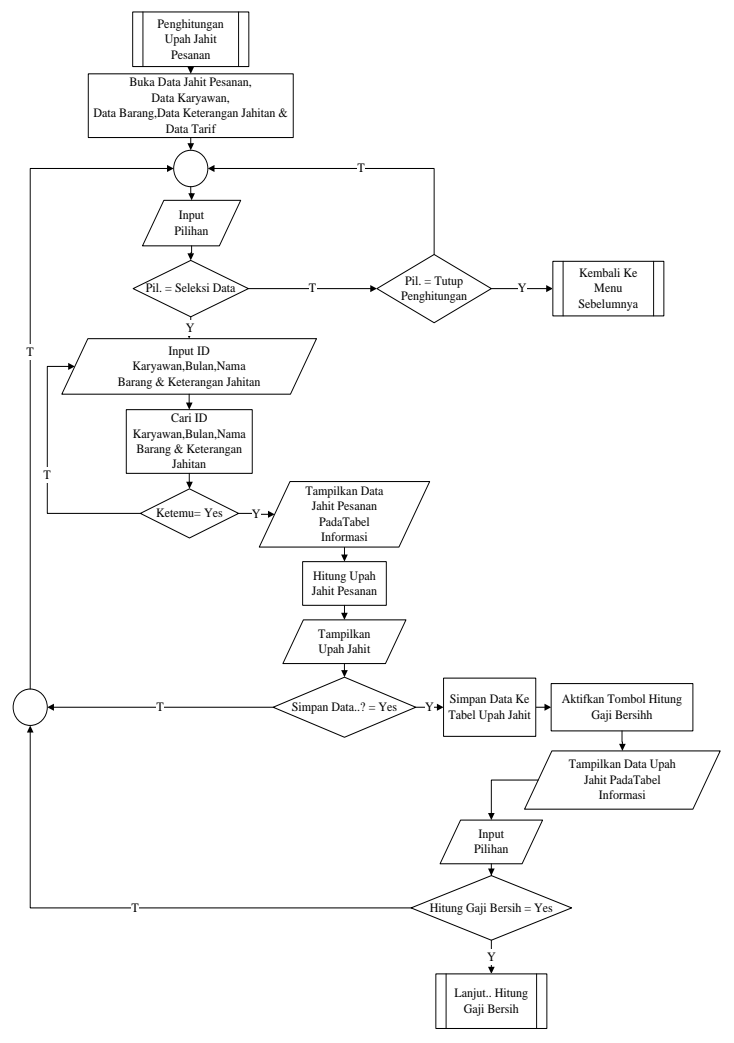

Gambar 3. Flowchart Perhitungan Upah

\section{a. Menu Utama}

Adanya menu utama pada sistem informasi menjadi panduan untuk ke proses yang berikutnya seperti pada Gambar 4 dibawah ini merupakan menu utama dari aplikasi yang terdiri dari home, proses, file, pengaturan, laporan, hak akses, tampilan.

\section{b. Upah jahit}

Merupakan form hitung upah jahit untuk karyawan berdasarkan jahitan yang dikerjakan yang ada pada Gambar 5 dengan keterangan hitungan berdasarkan perhelai, permeter sehingga menghasilkan total dari sub total pesanan jahitan. Tarif upah jahit berdasarkan kode barang jadi setiap barang memiliki tarif yang berbeda berdasarkan ukuran masing-masing seperti ukuran $1 \mathrm{~m}$, $2 \mathrm{~m}$, atau 2,5m sehingga memudahkan untuk memberikan informasi baik kepada pelanggan, karyawan atau pemilik

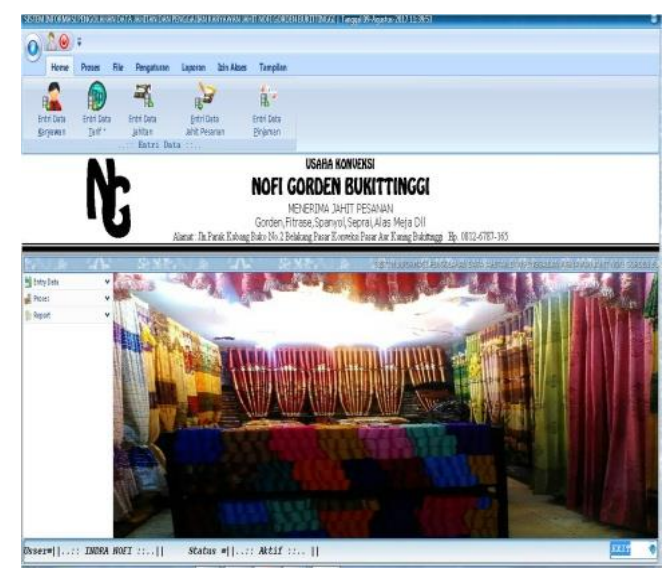

Gambar 4. Menu Utama

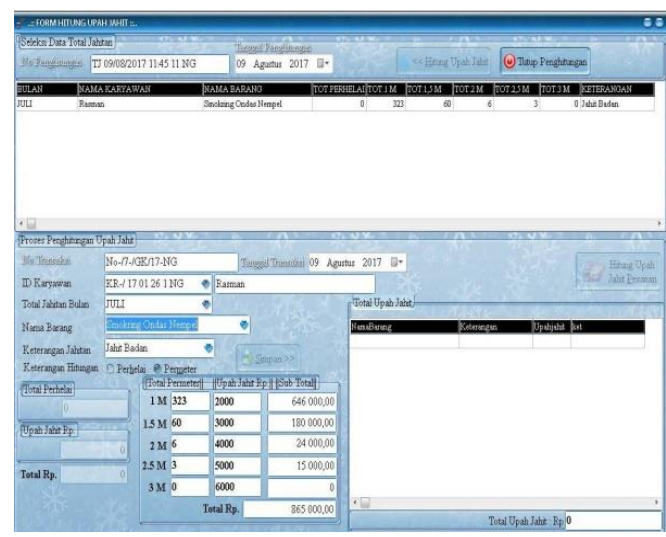

Gambar 5. Upah jahit

\section{c. Penggajian}

Seluruh proses data akan menghasilkan penggajian yang merupakan form transaksi perhitungan gaji karyawan per bulan pada Gambar 6 berdasarkan total upah jahit karyawan yang dikurangi dengan total pinjaman karyawan sehingga menghasilkan gaji bersih karyawan sesuai dengan data yang sebenarnya.

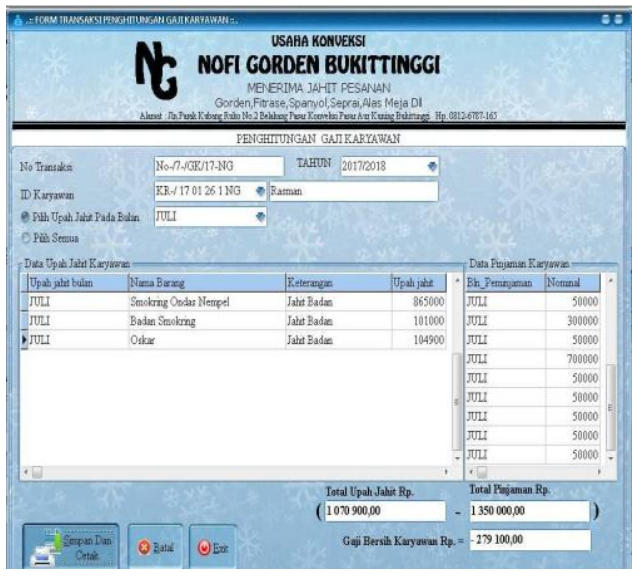

Gambar 6. Penggajian 


\section{d. Bukti pinjaman}

Laporan pinjaman dirancang karena tidak terlepas dari kebutuhan karyawan yang kadang kala melakukan peminjaman uang yang jumlah peminjaman akan dikurangi dengan total gaji yang didapat setiap bulannya. Dilaporan ini dimudahkan dengan no pinjaman dan terbilang sehingga membantu untuk data lebih akurat lagi sedangkan laporan rekap gaji karyawan juga bisa diproses pertahun yang ada pada Gambar 7 berdasarkan ID karyawan, nama karyawan dan jumlah gaji tiap bulannya.

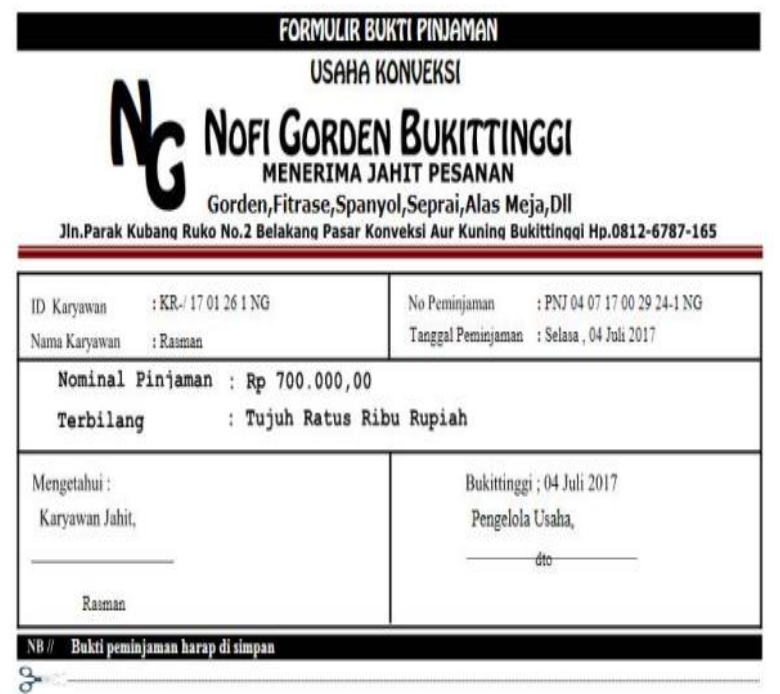

Gambar 7. Bukti Pinjaman

\section{Kesimpulan}

Sehubungan dengan analis is yang dilakukan pada usaha konveksi Nofi gorden dengan metode penelitian yang telah diuraikan maka kesimpulannya sebagai berikut :

\subsection{Simpulan}

1. Dengan adanya sistem komputerisasi dan database yang baik maka pengolahan data jahitan dan penggajian karyawan lebih cepat karena telah tersedia program aplikasi untuk melakukan pengentrian data jahitan dan laporan gaji lebih akurat

2. Untuk meningkatkan efisiensi dan pelayanan maka diperlukan suatu pengolahan data yang terstruktur agar menghasilkan informasi yang tepat bagi pengguna sistem dan memudahkan pengambilan keputusan oleh pimpinan yang sesuai dengan diharapkan dan manajemen keuangan dalam usaha juga lebih bagus dan mudah di kontrol.

\subsection{Saran}

1. Dengan penerapan sistem yang baru ini maka terlebih dahulu harus dilakukan penyesuaian dengan sistem yang ada sehingga sistem yang baru ini akan terasa keunggulanya dan kelebihannya dibanding dengan sistem yang sedang berjalan saat ini.
2. Diharapkan sistem yang dirancang ini bisa dikembangkan lagi berbasis e-commerce sehingga lebih dikenal masyarakat tentang usaha konveksi Nofi gorden Bukittinggi dan meningkatkan keuntungan pemilik serta penghasilan karyawan.

\section{Daftar Rujukan}

[1] Jogiyanto.H,Sistem Teknologi Informasi, Yogyakarta : Andi Offset, 2008

[2] Titin,P., 2013, Journal Speed - Sentra Penelitian Engineering dan Edukasi, Pembangunan Sistem Informasi Pengolahan Data Pegawai Dan Penggajian Pada Unit Pelaksana Teknis Taman Kanak-Kanak Dan Sekolah Dasar Kecamatan Pringkuku, Vol 5 No 2,pp. 1-6.

[3] Kani, Firmansyah, dan Sufandi, U. U. (2010). Pemrograman Dat abase menggunakan Delphi (Delphi Win32 dan MySQL5.0 Database Microsoft SQL Server. Jakarta: Elek Media Komputindo.

[4] Sutabri, Tata. Sistem Informasi Manajemen. Yogyakarta. Andi Offset. 2005

[5] Leon, A. A., 2006, Jurnal Ilmiah MATRIK, Perancangan Basisdata Sistem Informasi Penggajian, Vol.8 No.2,pp.135152.

[6] Dwi, J., dan Siska, I, 2014, Journal Speed Sentra Penelitian Engineering dan Edukasi, Sistem Informasi Penggajian Pada CV. Blumbang Sejati Pacitan, Vol 6 No 3.pp.36-43

[7] Madcom.(2004).Aplikasi Database Visual Basic 6.0 dengan Crystal Report.Yogyakarta: Andi Offset

[8] Yanuar, Y., dan Hakim, L. (2004). Pemrograman Delphidengan Optimalisasi Komponen ZeosDBO). Graha Ilmu: Jakarta.

[9] Scroggins,richard.2014, Journal Of Computer Science and Technology, SDLC and Development Methodologies.14,7.

[10] Supri Andoko, 2013, Speed Journal Indonesian Jurnal on Computer Science Pembuatan Sistem Komputerisasi Manajemen Penggajian Pada Comanditer Venoschaf (CV) Mobile Cell Pacitan, Vol 10 No.3.pp. 50-58. 